\title{
Rediscovering the Contributions of Forests and Trees to Transition Global Food Systems
}

\author{
James L. Chamberlain ${ }^{1, *}$, Dietrich Darr ${ }^{2}$ (I) and Kathrin Meinhold ${ }^{2}$ (1) \\ 1 USDA Forest Service, 1710 Research Center Drive, Blacksburg, VA 24060, USA \\ 2 Faculty of Life Sciences, Rhine-Waal University of Applied Sciences, Marie-Curie-Str. 1, \\ 47533 Kleve, Germany; dietrich.darr@hochschule-rhein-waal.de (D.D.); \\ kathrin.meinhold@hochschule-rhein-waal.de (K.M.) \\ * Correspondence: james.l.chamberlain@usda.gov
}

Received: 7 August 2020; Accepted: 12 October 2020; Published: 16 October 2020

\begin{abstract}
The importance of forests to safeguard agricultural production through regulating ecosystem services such as clean water, soil protection, and climate regulation is well documented, yet the contributions of forests and trees to provide food for the nutritional needs of the increasing human population has not been fully realized. Plants, fungi, and animals harvested from forests have long provided multiple benefits-for nutrition, health, income, and cultural purposes. Across the globe, the main element of "forest management" has been industrial wood production. Sourcing food from forests has been not even an afterthought but a subordinate activity that just happens and is largely invisible in official statistics. For many people, forests ensure a secure supply of essential foods and vital nutrients. For others, foraging forests for food offers cultural, recreational, and diversified culinary benefits. Increasingly, these products are perceived by consumers as being more "natural" and healthier than food from agricultural production. Forest-and wild-sourced products increasingly are being used as key ingredients in multiple billion dollar industries due to rising demand for "natural" food production. Consumer trends demonstrate growing interests in forest food gathering that involves biological processes and new forms of culturally embedded interactions with the natural world. Further, intensifying calls to "re-orient" agricultural production provides opportunities to expand the roles of forests in food production; to reset food systems by integrating forests and trees. We use examples of various plants, such as baobab, to explore ways forests and trees provide for food security and nutrition and illustrate elements of a framework to encourage integration of forests and trees. Forests and trees provide innovative opportunities and technological and logistical challenges to expand food systems and transition to a bioeconomy. This shift is essential to meet the expanding demand for secure and nutritious food, while conserving forest biodiversity.
\end{abstract}

Keywords: bioeconomy; food and nutrition security; forests and trees; forest foods; wild harvesting

\section{Introduction}

Global demand for food is projected to increase as much as threefold by 2050 [1]. By some estimates, food production will need to increase more than 70 percent over the next 40 years [2]. Supplying food to the growing world's population will put increasing demands on agricultural systems and land. With significant challenges to sustain past rates of yield increase for major agricultural crops in the future [3,4], the pressure to convert natural ecosystems and forest land to agricultural production will likely intensify [5], a practice that has led to tremendous loss of biodiversity. The conventional approach to achieving food security has resulted in a loss of forest cover that directly and indirectly supports the food security and nutritional needs of hundreds of millions of people, especially in developing countries. Hence, one of the greatest challenges of the 21st century is increasing food 
production to improve food security, without reducing forest area, or biodiversity, and at the same time not just feeding but nourishing people [6].

More than a billion people around the world depend on forests and trees for their livelihood, and forest foods for nutrition $[7,8]$. Rural people living proximal to forests derive a diverse set of foodstuffs from forests [9], which is particularly important for poor populations [10-12]. At the same time, wild foods are integral to the diets of vulnerable and higher-income urban populations in many parts of the world [13-17].

According to the high-level panel of experts on food security and nutrition of the Committee on World Food Security [18], forests contribute to food security and nutrition in several ways. Direct provision of food from forests may represents only less than one percent of global food supply, but the contribution to dietary quality and diversity is crucial to family health and wellbeing. Forest foods, especially fruits and vegetables are rich in the micronutrients that impoverished people often lack [19]. In 1997, approximately 390 million metric tons of food was produced by trees in developing countries [8]. On average, more than 258 metric tons of forest foods are reportedly harvested from public lands in the United States [20] each year. A recent study of households across Europe that collect forest foods found the mean to be about $60 \mathrm{~kg}$ per year, with a median of $20 \mathrm{~kg}$ [21].

Forests provide energy to process agricultural and forest foods for consumption. In general, wood fuel contributes about 6 percent of total primary energy supply, yet in some regions of Africa, wood fuel contributes upwards of 25 percent of energy needs [18]. In addition to the use of wood fuel for household subsistence, its sale and conversion into charcoal to supply urban centers provides employment and income opportunities in many rural areas [22]. In many developing countries, charcoal is the main energy source for urban households [23]. At the same time, fuelwood scarcity may negatively affect household food security and health, as typical household coping strategies include selling or bartering food to procure fuelwood, the use of lower-quality fuelwood substitutes such as dung, or reducing the amount of fuelwood use by eating fewer meals, undercooking food, or boiling water insufficiently to save fuelwood [24]. While the impact of fuelwood harvest on forests is highly context-specific, evidence suggests that harvest volumes can exceed sustainable levels $[25,26]$. Such negative environmental outcomes are partially attributed to the largely informal and unregulated wood fuel sector and wood fuel value chains with weak enforcement and governance mechanisms [27].

According to the FAO [6], commercialization of forest foods-and other forest products such as fuelwood-account for about 20 percent of income for rural households in developing countries. The formal forest sector employs more than 13 million people, providing income that allows for the purchase of food and other necessities [18]. Total income from production of non-wood forest products (a subset of non-timber forest products (NTFP)) is estimated to be more than 88 billion USD, although estimates are acknowledged widely to be lower than actual [28] (p. 25). Animal products (e.g., bushmeat, game) generate another 10.5 billion USD in income, and collection of medicinal and aromatic plants some 700 million USD [28]. Estimates of forest sector employment do not include the innumerable number of people worldwide that function in the informal forest economy, gathering for direct consumption, or bartering and trading products with no transaction records. By some estimates, more than 300 million people earn part of their annual livelihood and food from forests [8]. In some situations, food gathered from forests can reduce the family food budget as much as 60 percent [29].

Forests provide many products and services that are consumed by people everywhere, or used to serve their needs. A tremendous diversity of forest plants, fungi, and animals are harvested to provide food, medicine, and other essential and luxury items. While accounts of the roles forests have in human nutrition and food security via provision of food, energy, and income opportunities as illustrated are not inaccurate, we contend that they tend to neglect important and critical aspects-most importantly due to the informal nature of markets and consumption of forest products that is unaccounted for in official global statistics. Forests can indeed contribute to food systems at the local and global level in many further ways, as we demonstrate in the next section. While steps are being taken to improve the 
situation [30], more can be done. Recognizing these contributions is necessary to more fully account for and realize the forests' potential for sustainable human nutrition.

In this narrative, we focus on forest plants and fungi used as food, and forests and trees as provisioning units for food systems and the bioeconomy, by reviewing and synthesizing relevant literature and subsequently integrating the concepts. We start with an examination of the value of forests and trees to traditional and contemporary cultures, growing consumer demand for sustainable products, and potential public health risks. The myriad of production systems, from wild harvesting to single species plantations, are discussed. We then reflect on elements of a framework to encourage and support transition to a bioeconomy that integrates forests and trees to provide for food security and nutrition needs.

\section{Contributions of Forests and Trees to People in Food Systems}

\subsection{Cultural Identities and Nature-Related Values}

Indigenous people living in tropical and temperate regions have strong cultural ties to forest foods. The collection and use of forest plants and fungi to meet the nutritional needs of native peoples is deeply embedded in their cultures, with knowledge transferred through generations. For example, forest foods have contributed to the cultural identity of indigenous people across the temperate and boreal forest regions [31], as evidenced by the hundreds of edible plants documented contributing to diverse diets. Similarly, Native Americans have a long history of harvesting mushrooms for food and other purposes [32]. Likewise, traditional hunter-gatherers in the Congo basin subsisted for extended periods by foraging wild forest food, such as wild yams [33]. Contrary to native populations in Canada and Mexico, Amazonian Indians tended to consume fewer wild greens but preferred wild fruits and tubers [34]. The sharing of knowledge about these forest foods adds to the edification of next generations and can provide valuable insights into managing forests for these resources.

In addition to the cultures of native peoples, forest foods embody significant importance to the cultural identity, lifestyles, and intangible values of urban populations. Foraging landscapes for food is very much a part of urban cultures around the world and has increased in popularity over the last two decades. A simple search of the social media platform, Facebook, reveals many groups formed around foraging food from natural habitats. The global membership of foragers on Facebook have commonality in the culture of food plants and share information and knowledge to promote their practices. In Berlin, urban residents commonly use and consume wild plants for food, personal joy, and medicinal uses [35]. The collection of wild onions, also known as ramps or leeks (Allium tricoccum Ait.) from the forests of Appalachia, in the US, is deeply embedded in the region's culture and has grown in popularity among urban consumers over the last 25 years [36]. With the collection of wild mushrooms and other forest foods gaining popularity among urban middle class and hipster populations in Sweden since the 20th century, a vivid community has developed providing related educational and support services including evening classes, study circles, clubs, and exhibitions [37]. Foraging for forest foods is supporting a renaissance among urban cultures around the world and may have significant impacts on forest-based economies and ecologies [38]. The demographics of contemporary foragers suggest that verified sustainable sourcing of forest foods would be important to these consumers and advocates.

Studies have highlighted the roles of formal education systems in mainstreaming the contribution of wild edible plants in human diets. For example, a progressive school in Berlin, Germany, that offered regionally produced food provided opportunities to grow fruit and vegetables in the school's garden and foraging wild edible plants from a neighboring vacant plot; it was involved in the collaborative planning and management of their food production and found that students were better educated about nature and food production and had improved their diets [39]. Some Native American tribes, such as the Eastern Band of the Cherokee Indians, are integrating traditional foods into their educational programs. Conversely, formal education systems in some Chilean traditional communities largely 
neglect local knowledge of traditional food plants and their uses, contributing to a process of biocultural homogenization that leads to reduced use of biodiversity for household nutrition [40].

\subsection{Satisfying Consumer Demand for Healthy, Sustainably Produced Natural Foods}

Undeniably, forest foods provide the calories and macro- and micronutrients essential for human nourishment. More broadly, they contribute to meeting the diversifying culinary demands of a changing global population. Economic advancement, increasing levels of income and living standards, and the emergence of an urban middle class in many countries have prompted significant transitions of diets, eating habits, and consumer preferences related to food products. Changing socioeconomic conditions and the modernization of lifestyles lead to a growing diversity of consumer tastes and preferences [41-43]. Nevertheless, among the major food-related consumer trends are the increasing demand for healthy, sustainably produced, and convenience food products [44], the latter denoting increasing demand for food products that aim to reduce the time and effort required by consumers to buy, store, prepare, and consume their food. This is largely triggered by sociodemographic changes such as the increasing number of single households, declining culinary skills, and more stressful lifestyles and has led to a diversity of fresh, ready-to-eat, single-portion packaged, snack, or pre-prepared food products [44]. Forest foods can contribute to satisfying these demands. Wiersum [38] describes the increasing appreciation of forest foods in Europe as driven by a growing interest in heritage-inspired and more natural forest production systems and experimentation with new biocultural practices.

While forest foods have been portrayed as old fashioned and reserved for the poor [45,46], there is evidence that wild edible plants are perceived positively by more affluent consumers [13,47] and some have been integrated into mainstream markets. Consequently, there is increasing potential for wild foods to contribute to bioeconomies as sources of sustainable, healthy raw material [48]. For example, wild edible fruits and other forest foods often are perceived by consumers as being healthy and nutritious and linked to cultural identity [16,36,49,50]. Aworh [13] reports that some African traditional leafy vegetables, including tree leaves, are increasingly being offered in fine dining restaurants and supermarket chains in urban centers of Kenya and other African countries. Other studies provide evidence that, while traditionally linked to consumption by rural poor and as a safety net in times of food shortage, some forest foods, such as baobab (Adansonia digitata L.), are increasingly processed into high-value food products and sold to high-income consumer segments through local urban specialty and delicacy stores in Malawi [51] or in international markets [52]. Similar reports also exist for shea (Vitellaria paradoxa C.F. Gaertn), acai (Euterpe oleracea Mart.), pine nuts, or edible insects (e.g., Ruspolia differens Scopoli). At the same time, technological advancements facilitate the use of wood products for processing into food ingredients for mainstream markets, as demonstrated by the importance of xylitol produced from birch wood (Betula pendula Roth.) in Finland as a low-calorie sweetener possessing dental health benefits [53]. Hence, forests have significant potential to supply healthy, natural, and sustainably produced food products that health-conscious and sustainability-oriented consumer would buy and are beginning to be considered in discussions about "future smart food". Transitioning to a bioeconomy may spur this shift more rapidly.

\subsection{Public Health-Contributions and Risks}

While forest and trees contribute to improving public health, there also are potential risks to consuming forest foods. Studies have confirmed the antioxidant, antihypercholesterolemic, antidiabetic, anti-inflammatory, anti-amyloidogenic, antimutagenic, antiviral, or antimicrobial activity of phytochemical compounds contained in wild edible plants [54]. Integration of forest foods into food systems, by altering consumption habits and preferences, production, harvesting and processing practices, and the structure and governance mechanisms of food value chains, could contribute to reducing malnutrition [55]. Food production systems that include forest foods could appropriately address undernourishment, food insecurity, and micronutrient deficiency, problems that affect more than 800 million people, particularly in the Global South [6]. In addition, integrated 
food systems can contribute to halting and reversing the prevalence and severity of diabetes [56], cancer [57], cardiovascular [58], and other non-communicable diseases related to dietary excess and physical inactivity.

Conversely, consumption of forest foods can increase exposure to human health risks. For example, due to the increasing popularity of collecting mushrooms and wild plants by city dwellers, accidental poisoning may occur more frequently if they are mixed with similar-looking inedible or even poisonous plants. For example, confusing self-collected wild garlic (Allium ursinum L.) with lily of the valley (Convallaria majalis L.) has tremendous risks as the latter has high content of digitalis glycosides [59]. Furthermore, the hunting, handling, processing, and consumption of bushmeat can increase the occurrence of wildlife zoonotic diseases, the emergence and spread of which has been amplified by changes in climate, land use, and biodiversity [60]. In many cases, disadvantaged social groups, particularly, are most affected by these risks. In Cameroon, marginalized groups of young, poorly educated, jobless hunters and women preparing bat meat for consumption were exposed to the risk of Ebola virus infections [61]. Likewise, households with a lower food security status hunted and consumed a larger diversity of bushmeat species, which along with the potential increased negative impacts on wildlife conservation also increased their risk of infections with zoonotic diseases [62]. Moves to ban wildlife consumption, particularly in view of the Covid-19 pandemic, may have unintended consequences particularly on those who depend on wild meat for nutrition. It is important to not demonize foraged foods, but instead increase awareness on proper handling, harvesting, and consumption. Aversions to risks such as these may be overshadowed by the urgent need to feed families.

\section{Forests and Tree Food Production}

Forests are an assemblage of fauna and flora that form a system of mutual benefits. The plants that make up forests include forbs, grasses, and herbaceous plants that cover the forest floor, shrubs, and other woody species that inhabit an understory created by trees that dominate overhead. Traditionally, forests have been perceived as large expanses of land dominated by trees. A more contemporary perspective on "forests" include trees in all of their settings: natural and manipulated habitats, agroforests, single-species plantings, and on lands where they are not the dominant growth habit, such as fields, roadsides and urban landscapes. Natural forests provide tremendous biodiversity harvested for food for local and nonlocal consumption. Agroforests that integrate trees and crops are designed to provide food products directly and protective services (e.g., soil erosion, habitat for pollinators, mitigating microclimate conditions) to improve production. Secondary forests and single-species plantations provide many food products for self-consumption and for commodity markets. Trees outside of these habitats provide food valued by urban and rural households, as well as others. Fields and urban landscapes often have trees that produce food and other important products. Figure 1 illustrates contributions of forest and trees to food systems.

Production of forest foods range from unmanaged wild foraging to highly managed single-species plantations [29]. Some production systems appear to be random accumulation of plants with few inputs, while others are very organized with high human interventions. The scale of production depends greatly on the purpose and demand for the products. Conceivably, the amount of forest foods needed for direct household consumption are less than amounts wanted for income generation. In many countries, harvesting forest foods is embedded in the culture, and access is uninhibited because the products are considered public resources.

Forests have been altered by people living in and near them for millennia [63]. Evidence indicates that people have "managed" forests to increase food production for tens of thousands of years, and that most forests have been changed significantly over time to provide for the direct nutritional needs of families [64-66]. As Parrotta et al. [63] indicate, many forms of traditional forest management that include food production-such as multi-storied agroforests, home gardens, and shifting cultivation—remain but are undervalued for their contributions. 


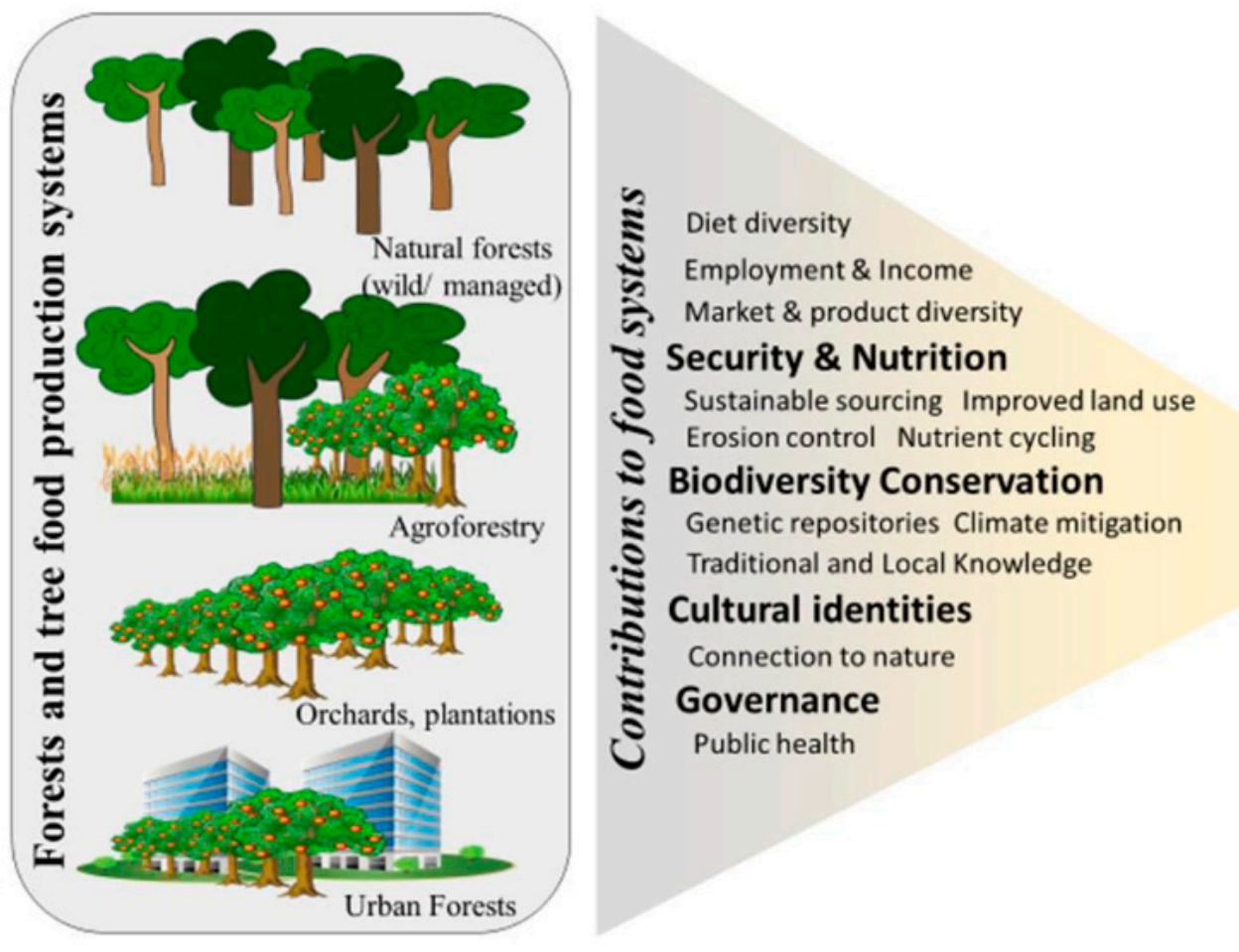

Figure 1. Contributions of forest and trees to food systems.

\subsection{Wild Harvesting/Foraging}

People have been foraging food from forests since the beginning of time. Wild-harvesting forest foods supported families and communities since before agricultural technologies made it possible to grow food in fields. Long before the technologies existed to grow food, indigenous people were harvesting food from forests for direct consumption. With technological developments that allowed for food production in fields, demand for forest foods may have decreased, but forests continue to supply critical nutritional needs to families and communities. It is fundamental to the identities of cultures around the world, and many forest food plants are considered cultural key stone species [67] that identify the people who depend on them. The loss of these species or access to the plants would drastically affect the people and their cultures.

Given that foraging often takes place on open-access or communal lands and involves some competition over the resource between foragers, some communities of foragers have developed governance and management practices to ensure production of these forest foods. In northeastern Brazil, harvesters of pequi (Caryocar coriaceum Wittn) have rules on how to harvest the fruit to maximize quality without detriment to future harvests or the vitality of the tree [68]. Management by Native Americans by pruning or coppicing has been shown to increase biomass production in some forest plants [69]. Some Native American tribes, such as the Eastern Band of the Cherokee Indians, have formal forest management plans with explicit objectives for production of traditional foods [70]. Formal regulations have been established by many US state governments to manage the harvest of American ginseng roots to encourage conservation [71]. Traditional and local knowledge can inform better management of forests for wild foods. However, the effectiveness of governance systems may strongly differ or lead to unintended consequences [72,73].

Wild harvesting of forest food often is perceived to be done with little or no science-based management [74]. Many contemporary foragers have developed management strategies to ensure long-term sourcing of the products. Longtime harvesters of Allium tricoccum (ramps, leeks) in the US may rotate harvest sites and select larger leafed plants to help manage the resource [36]. In some situations, such as berry harvesting in northern European countries, cultural harvesting practices 
have integrated with science-based knowledge to ensure management of the resources to supply contemporary demands for forest foods.

\subsection{Managed Forests}

Traditional forestry organizations, in general have not managed forests for food, although silvicultural practices, used for timber production, may provide opportunities to support food production needs $[31,70,74]$. The inclusion of food bearing plants in forest management can improve biodiversity conservation while addressing food security and nutrition. For example, spring ephemeral forest herbs, such as Allium spp., are harvested for food and contribute to nitrogen cycling; improving forest health while providing sustenance to humans. Managing forests for American ginseng, a medicinal plant, would require extending the rotation length for timber, reducing pressures from nonnative invasive plants, and encouraging growth of native understory plants [70,71]. Thinning forest stands may improve conditions for some food plants, such as berries, but may decrease production of others, such as mushrooms [75]. Managing forests for forest foods requires consideration of the impacts silvicultural treatments have on associated resources.

One of the rare examples of natural forests that are being managed primarily for forest foods are the walnut (Juglans regia L.) fruit forests in Kyrgyzstan. Due to the high number and genetic diversity of crop wild relatives that these forests harbor and their environmental importance for slope stabilization and equalization of water flows across seasons for downstream agricultural irrigation areas, these forests have been classified as protected forests since during Soviet times [76]. The production of walnut and other wild edible plants such as apples, plums, barberry, and rosehip were-and still are-important forest management objectives. In addition, limited quantities of timber and fuelwood were to be harvested through sanitary felling, regular thinning, and felling to induce forest rejuvenation according to management plans. It has been shown that careful silvicultural interventions can improve the stability and quality of stands and the production of walnut fruits [77]. However, due to weak enforcement of legal norms, and tremendous economic pressures, these forests have been continuously affected by uncontrolled and partially illegal timber exploitation, ineffective forest restoration measures, extraction of unsustainable amounts of fuelwood and commercial NTFP, and overgrazing [72]. This negatively affects the production of walnut and other forest foods.

Silvicultural prescriptions for forest foods require consideration of the impacts on resource availability [78,79]. Changing light and moisture regimes can have beneficial and detrimental impacts to forest plants desired for food. Creating gaps in the forest canopies can improve habitat for berries and other plants that like lots of sun. Conversely, gaps can increase the light getting to the forest floor to the detriment of shade loving plants. Some forest plants, such as hazelnuts (Corylus spp.), survive in the shade of forest canopies but need more light to produce fruit [31]. As production of maple syrup is directly related to the amount of foliage, trees managed for sap often are thinned and widely spaced to encourage large-crowned trees [80]. Although this may not be conducive to co-management for timber, it may present opportunities to grow understory food-producing plants, such as ramps in agroforestry.

\subsection{Agroforests}

A significant amount of wild foods come from agricultural lands that have some tree cover [6,29]. Agroforestry, a collection of food production systems, integrates woody perennial plants with agricultural production in spatial and temporal combinations with the intent of improving productivity, encouraging positive interactions within the system, without compromising future production potential [63]. Zomer et al. [81] estimated that over a billion ha worldwide of all agricultural lands were under some sort of agroforestry (i.e., agricultural lands with more than 10 percent tree cover) and ranging from the purposeful retention of naturally occurring trees on farms [82] to the establishment of multi-layered home gardens composed of annual and perennial herbs, shrubs, trees, and vines [83]. Zomer et al. [81] estimated that more than 96 percent of the agricultural lands in Central America were classified as agroforestry, while that proportion was over 80 percent in Southeast Asia 
and South America. Over the decade ending in 2010, Zomer et al. [81] estimated that agroforestry lands increased 3 percentage points, more than 82 million ha.

Agroforestry systems support food security and nutrition directly and indirectly through a number of ways. For one, they provide ecosystem services and positive livelihood impacts $[82,84]$. By integrating native trees in their production system farmers can generate additional income, directly benefit from nutritious food products, and increase their resilience to market or climatic shocks $[85,86]$. Furthermore, agroforestry can help maintain tree and associated biodiversity [87], reduce soil erosion, and improve soil characteristics, which can increase crop yield and household food availability year-round $[88,89]$. As an example, traditional agroforestry systems in Indonesia are associated with more frequent consumption of healthy foods than natural forests or tree crop plantations, as they are known for the diversity of crops and management of wild foods [19]. Home gardens in Uganda significantly contribute to household nutrition security, compared to anticipated shifts in industrial agricultural systems envisioned by governmental strategies [90].

Agroforestry systems with native fruit trees and traditional forest foods can be of particular interest to achieve nutrition and food security objectives given that many forest fruits and plants are important sources of macro- and micronutrients. However, bottlenecks limit the benefits from indigenous fruits produced in traditional agroforestry systems [91], among them market insufficiencies and failures such as limited demand, inadequate supply, and marketing channels or supply control mechanisms [92-94]. One strategy to realize the potential of native fruit tree species in traditional agroforestry systems to enhance food security, livelihoods, and resilience for future challenges, is to stimulate emergence of markets and development and promotion of businesses and innovations to meet the arising market demand [95].

\subsection{Orchards and Plantations}

Single species plantings of food-producing trees provide significantly to security and nutritional needs. Hundreds of tree species are cultivated by households for direct consumption and for sale. Smith et al. [96] estimated that more than 170 tropical and subtropical tree species are under cultivation. A subset of these are grown for international commodities markets, and a few are being grown for these markets on a large scale by small landholders [97].

Many non-timber forest species undergo a "dynamic process of domestication" that transgresses their collection from the wild and often includes their simultaneous cultivation on farms [98]. Certainly, there is a progression of sourcing forest foods that originate in natural habitats of gathering fruits and proceeds to growing fruit around homes. When production of home grown fruit can no longer supply peoples' desires, trees would be planted in clusters, or orchards and plantations. For example, for baobab, it has now been shown that its density is often higher in villages and fields in contrast to natural plains [99]. While a number of NTFP of high commercial value are grown in intensively managed plantations (e.g., rubber, oil palm, walnuts) and, hence, commonly considered as agricultural crops rather than forest products, some of these products are predominantly still being produced by small-scale and/or non-industrial producers. For example, in some parts of China, approximately 90 percent of the walnut plantations were managed by smallholder farmers [100]. With a total production volume of 1.6 million tons of walnuts with shell harvested from approximately 390 thousand ha of walnut plantations in 2018 [101], China has displaced the US as the leading global walnut producer already since the 1990s. The cultivation of walnuts in smallholder orchards and plantations provides important livelihoods, contributes to household incomes, and is significant in terms of food production in the Central Asian highlands and many of the countries along the Silk Road [102]. There is great potential to increase the contribution of such smallholder-managed plantations to global food production by improving management for this and other food bearing trees. For example, the largely non-industrial walnut plantations in India yielded only $0.84 \mathrm{t} / \mathrm{ha}$ [103]; in China, yields were about $2.3 \mathrm{t} / \mathrm{ha}$, and in Iran, yields were about $2.5 \mathrm{t} / \mathrm{ha}$ [104], while well-managed industrial walnut plantations in California, U.S., can attain average yields of $4.2 \mathrm{t} / \mathrm{ha}$. This yield gap is 
typically caused by a lack of advanced propagation techniques, root stocks, and cultivars, as well as lack or sub-optimal use of agronomic inputs such as irrigation, fertilizer, or pesticides.

\subsection{Urban and Peri-Urban}

A small portion of the estimated $600,000 \mathrm{~km}^{2}$ [105] of urban and peri-urban land in the world produces over 15 percent of the world's food [106]. In the US alone, more than $6400 \mathrm{~km}^{2}$ of urban land could be planted with food bearing trees and contribute to food production systems [106]. A diversity of urban habitats, such as city parks, campuses, street trees, urban woodlots, cemeteries, residential yards, and allotment gardens, provide plant material and fungi to urban foragers [107]. While urban foragers may depend on these food resources to varying degrees, from occasional recreational use to regular livelihood supplement, collection of foods from urban environments embodies important aspects of urban well-being [107]. Estimates suggest that daily recommended minimum intake of fruit could be achieved via planting fruit trees in publicly accessible open spaces [106]. Despite its importance, the foraging of food products on public lands is often neglected, heavily regulated, or even prohibited in many places [107-109].

At the same time that urban lands could be sources of tree foods, cities are major pollution hotspots, and hence, urban food security aspects need to be balanced with concern for food safety. Of particular relevance is the uptake and translocation of pollutants such as heavy metals from contaminated soils or airborne metal emissions to plant edible parts [110]. For example, wild mushrooms collected from urban habitats in Berlin, Germany, accumulated extremely high amounts of lead and cadmium and did not meet the EU standards for these trace metals in 86 percent and 54 percent of the cases [111]. Yet, circumstantial evidence from the San Francisco East Bay [112], in the US, indicated that wild edible plants grown in soils with elevated heavy metal concentrations in high-traffic industrial urban areas were safe to eat after rinsing in tap water. Yet, such concerns are not limited to urban and peri-urban areas as contamination of wild fish, meat, and plants with heavy metals can occur in natural ecosystems, whence these resources inhabit due to geological conditions, such as the Kamchatka region in the Russia Far East [113].

\section{Realigning Food Systems for Forests and Trees}

Clearly, forests contribute much to the provisioning of food, for direct consumption, and indirectly for income generation to purchase food. Markets for forests foods, such as baobab, range from local-based that supply households or communities, to global and corporate-based, serving multiple countries. Unlike agricultural and timber-based commodities, the value chains for forest foods are less developed or understood [114]. They may supply segments of industries (e.g., pharmaceuticals, nutraceuticals, natural foods, health foods) that are enigmatic to agricultural or forestry institutions that set policies, track production, and promote innovation and market opportunities. As such, many of these products remain invisible in national and international governance and lacking in resource management and production. [30]. Integration into, and acceptance by, appropriate institutions could increase visibility of their importance. Approval of baobab fruit pulp as a safe novel food would open European markets to the export of this African-grown product [115]. International discussions such as on the acceptance and use of "novel foods", or the related access rights and benefit sharing mechanisms with local communities under the Nagoya protocol can contribute [116,117] to increasing the attention on the importance of forests for these "other" resources. Fostering a transition to an integrated food system that includes forests and trees, involves innovative new business models and products, and markets that are driven by progressive consumer awareness and demand, with governance by stakeholders at all levels, and evidence-based sustainable forest management and production (Figure 2). In essence, these elements support a framework for transitioning to a bioeconomy that can meet increasing global demand for healthy and nutritious food and increasing concerns for biodiversity conservation. 


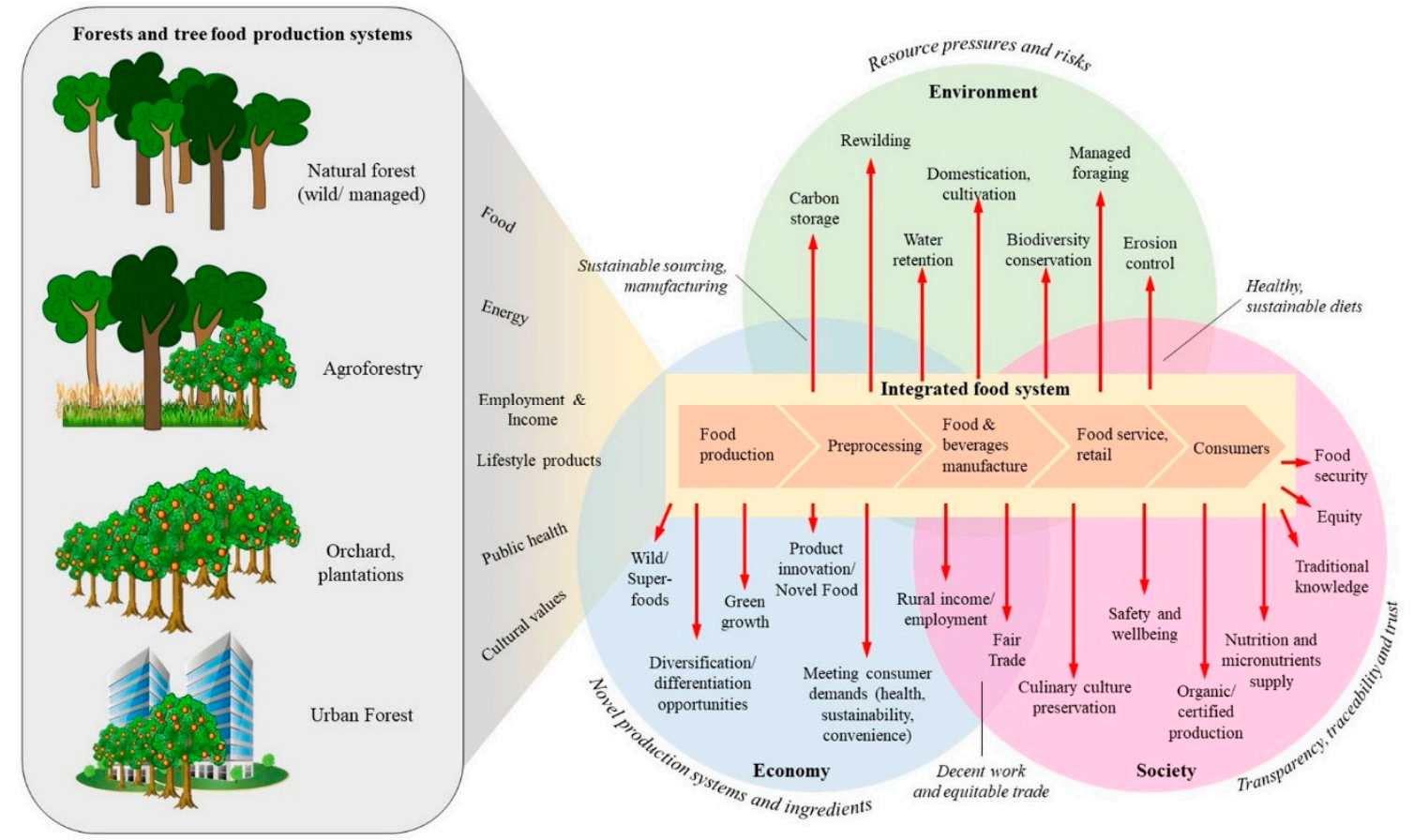

Figure 2. Integration of forests and trees into food systems has many elements that lead to a framework for transitioning to a bioeconomy. Source: modified from food system framework as presented by the Institute of Food Science and Technology [118].

\subsection{Shift to a Bioeconomy}

Realignment of forest production systems and management to integrate into food systems will require a fundamental change in priorities to include edible plants and fungi (and animals). In a bioeconomy, the intrinsic values of forests to supply healthy and nutritious natural foods are recognized, meaning that even though the economic value of forest foods may be less than for other resources, the contribution of forests to food security and nutrition are integrated into economic planning and resource management. A fundamental element to support transitioning to a bioeconomy is full recognition that edible forest resources are natural resources that require management efforts similar to other forest products. With this awareness, a pathway from status quo to a more progressive bio-based economy can be charted.

The bioeconomy is emerging as a major strategic economic movement of the 21st century [119-122]. The motivation driving this was originally oriented on biotechnology to replace fossil fuels with biofuels, particularly wood fuels, and other alternative energy. Ensuring and producing healthy and safe food are viewed by some as central objectives of a bioeconomy $[123,124]$. The path to a bioeconomy will touch all levels of society, from consumers to producers. It is based on sustainably and equitably sourcing products, with little or no negative environmental impacts, and supported with strong science-based knowledge. Figure 2 illustrates elements to the three foundational pillars (i.e., economy, society, ecology) of sustainable bio-based economies, and the contributions from forests and trees in integrated food systems.

Although, they have been, and continue to be, a major part of the global economy, edible forest products remain under-valued in the forest-based economy. For the most part, this economic model includes primarily wood-based products. However, a great deal of forest biodiversity is harvested for non-wood products that contribute to bio-based economies. Forest foods, such as from baobab, provide opportunities for transitioning to a bioeconomy that serves diverse markets, innovates to supply sustainably sourced products, and incorporates arrangements that promote Fair Trade and other social-equity systems. Investment in "green" market infrastructure to improve production, processing, and distribution may help to facilitate a transition to such a model. 


\subsection{Forests and Trees as Provisioning Units}

Forest production systems and their management to include foods will expand beyond "traditional" objectives in transitioning to a bioeconomy. Management decisions, analyses, plans, and actions will expand to include food production possibilities. The general concept of multiple-use forest management [125] would expand to include food products and associated services. The ecosystem management paradigm [126,127] would include the manipulation of forests for production of food. In a transition to a bioeconomy, forest production systems expand to include societal costs and benefits related to more healthy food consumption, optimizing timber production, while providing environmental services to society.

In a bioeconomy, forest foods are produced in a variety of systems; forests that are open to wild harvesting, forests managed for food, agroforests, urban and peri-urban forested landscapes, and where appropriate, single-species plantings. They blend into diverse mosaics of habitats across landscapes. This would include trees outside of traditionally perceived forests, across a spectrum of land uses to natural forest settings that may serve as refugia for biodiversity. For most efficient production, single-species plantings would be strategically located, while agroforests would blend into the landscape, providing food and other products for personal consumption and to supplement incomes. Urban trees would be managed by the people and communities where they live.

While sustainably harvested for local consumption over generations, more intensive utilization of some forest food species may be related to significant negative impacts on forest ecosystems and biodiversity. For this reason, a transition to a bioeconomy may entail domestication and cultivation in more intensively managed production systems outside natural forests. In a bioeconomy these and other systems would adhere to evidence-based production practices to supply sustainably sourced products.

\subsection{Consumer Demand Pushing Innovative Business Models}

Ultimately, consumer awareness, demand, and support will drive a shift to a bioeconomy. The growing population of urban consumers who want sustainably harvested, all-natural, locally, and justly produced products are creating the demand for such a shift [38,44,128,129]. These consumers are more likely to demand Fair Trade products that are certified sustainably and organically sourced. Consumer demand for forest foods that are socially, economically, and ecologically respectful as well as increasing regulatory push will spur industry to supply such products. Social marketing $[130,131]$ to this demographic could generate energy to transition from the status quo. The more that consumers demand these kinds of products, the more motivation the industry has to innovate.

Policy actions at the global and national levels could encourage industry shifts more expeditiously. A transition to a bioeconomy may spur new and creative business models (Figure 2) and investment in product innovation and technology development to satisfy growing demand for healthy, sustainable, and fairly sourced foods. Identification, domestication, and cultivation of promising species, planted in appropriate systems to satisfy the growing demand for healthy, sustainable, and fairly sourced foods are elemental for a transition. Further, innovation in processing, distribution and marketing, and other elements of value chains may stimulate transitions in local and global economies.

\subsection{Innovation Opportunities}

A diverse range of sectors (e.g., pharmaceuticals, nutraceuticals) in the functional food industry, companies that manufacture natural and homeopathic preparations, are constantly searching for new, as yet uncharacterized, plant-based raw materials. They are looking for natural substances that can replace artificial ingredients to extend product shelf life, improve technological properties, or have other properties that are valued by consumers (e.g., taste), which do not have to be declared on food labels due to their natural origin, which will help to expand their product portfolios and retain competitive advantage. Phytochemicals contained in trees and forest plants provide significant opportunities for development of new food products $[128,129]$. In view of the trend towards healthy 
nutrition and the growing demand for food products containing natural ingredients, new, natural food colorants, flavors, and functional ingredients are gaining importance. Natural ingredients of plant origin, which are much better accepted, or perceived as adding value, by critical and increasingly well-informed consumers, are of particular interest to a progressive food industry [44,57]. For example, natural colorants derived from fruits, such as anthocyanins, betalains, carotenoids, and chlorophylls possess bioactive properties in addition to their coloring ability [132]. In contrast, synthetic additives are sometimes suspected of causing allergic reactions or triggering ADHD syndrome in children [133]. Many wild products however are hidden ingredients in food, pharmacological, and cosmetic industries and are not sustainably or ethically sourced and, in some cases, contributing to the depletion of valuable species.

Forest biodiversity provides an unlimited reservoir of potentially useful substances, as the phytochemical composition of most forest plant species has yet to be thoroughly characterized. As an example, extracts from the male flower of sweet chestnut (Castanea sativa Mill.) used as an alternative to potassium sorbate in pastry products increased contents of reducing agents and radical scavengers, while maintaining the nutritional and chemical profiles of the pastry [134]. So-called superfruits such as Acai (Euterpe oleracea Martius), Acerola (Malphigia emarginata D.C.), Camu-camu (Myrciaria dubia (Kunith) McVaugh), Goji berry (Lycium barbarum L.), Jaboticaba (Myrciaria cauliflora (Mart.) O. Berg), Jambolão (Syzygium cumini (L.) Skeels)), Maqui (Aristotelia chilensis (Molina) Stuntz), Noni fruit (Morinda citrifolia L.), and Pitanga (Eugenia uniflora L.) contain a variety of phytochemicals (e.g., phenolic acids, flavonoids, proanthocyanidins, iridoids, coumarins, hydrolysable tannins, carotenoids, and anthocyanins) that have promising health benefits to humans [135]. Clinical trials have confirmed many of these effects in vitro and in vivo. For example, human intervention studies suggest that the juice of the noni berries from French Polynesia may provide a number of health benefits, including protection against tobacco smoke-induced DNA damage, blood lipid and homocysteine elevation, and systemic inflammation [136]. Baobab-enriched bread has been shown to reduce starch digestion and glycemic response in humans [137].

A re-emerging trend shows growing interest in foraging forest foods, described by Wiersum [38] as a relatively new multidimensional phenomenon, which involves biological processes of "re-wildering" and new culturally embedded interactions between people and nature. Some key examples of ingredients from forests and tress include baobab, moringa (Moringa oleifera L.), shea butter, argan (Argania spinose L.), and pygeum (Prunus africana (Hook. F.) Kalkman). All are sourced to supply multiple, billion-dollar industries that serve growing demand for "natural" food production. A transition to an integrated food system would leverage the true potential of forest foods to satisfy global food production, including changing food-related preferences and behaviors of consumers. It would acknowledge the importance of forest foods vis-à-vis agricultural food production; the structure and governance of forest food value chains; and quality and food safety aspects of provisioning forest food.

\subsection{Processing, Marketing, Distribution}

Transitioning to a bioeconomy may involve changes to the processing, marketing, and distribution of forest foods. Distribution channels range from traditional, local markets to highly sophisticated global supply chains. Forest foods such as maple syrup or acai and baobab powder are processed as ingredients in a wide range of food products and can be found in global markets. Most forest foods, however, are still sold unprocessed and undergo limited value-added processing. More local processing to add value to products could, however, have positive effects on income and profits [138,139]. The distribution of benefits, however, depends greatly on the value chain structure and governance, as middlemen or elite traders may inhibit smallholder producers from realizing more benefits. Processing may contribute to preserving forests foods, so that they can be distributed to more distant markets, although processing may impact the nutritional qualities of the products. Many forests foods are available only in local or regional markets with relatively short distribution chains. Reaching high-value export markets may be a worthwhile strategy for some forest foods, but these markets may be difficult for smallholder 
producers to enter and may be very risky for less affluent producers. A focus on local markets is linked to consumer preference for locally produced food products traded through short supply chains [140]. Hence, local market development that benefits small producers would be an important element for a bioeconomy strategy [140].

Different approaches have been used, such as Fair Trade, Fair Wild, and organic certification, to ensure higher sustainability in the production and equitable sharing of benefits from utilization of natural resource. Studies show that consumers are willing to purchase and to pay premium prices for food products with attributes such as local production, organic or sustainable production, social fairness, or geographical indication [42,141]. The provision of health information on packaging labels can increase consumers' willingness to pay [42,142]. The comparatively high costs involved in obtaining certification, however, hinders their wider acceptance, particularly for small-scale producers and companies. To encourage participation and transition to a bioeconomy, some organizations are providing cost-share programs and other incentives to reduce financial burdens of certification.

Special considerations for food quality and safety are needed to target some more advanced markets. To integrate forest foods into agricultural-based food systems will require similar quality and safety standards. A few forest foods, such as shea and Arabic gum, have associated standards under the Codex Alimentarius International Food Standards [143]. Establishing standards may be complicated by high intra-species variety within wild forest foods and inferior product attributes (e.g., size or sugar content) compared to cultivated products [144]. Forests foods typically do not undergo quality checks for local markets similar to agricultural production practices, which may raise concerns considering food safety (e.g., microbiological contamination due to insufficient post-harvest handling, risk of zoonosis in the case of bushmeat), and may limit access to export markets. Such issues may counteract positive effects from nutritional composition of forest foods. As noted, consumer awareness and preferences for healthy, natural, and sustainably sourced food, quality, and safety of forest foods could be a major driver in transitioning to a bio-based economy.

\subsection{Knowledge and Governance}

Integrated food systems with forests and trees recognize the contributions of traditional and local knowledge and governance by the array of stakeholders. A bioeconomy strategy incorporates knowledge systems with science and policy to the design and implementation of sustainable food systems that includes stakeholder knowledge from all levels. Many food systems are based on traditional land-use practices, and some have been the subject of a great deal of scientific analyses. The combined knowledge can lead to better management for improved local conditions.

In general, forest governance in a bioeconomy strategy would be inclusive of all stakeholders. Stakeholders at all levels of society would be involved in conversations and dialogue about managing all forest resources. Management of the forest bioeconomy would be vertically integrated to include value chains with fair and equitable distribution of benefits. State agencies would partner with local communities and private entities to manage forests for the benefit of all. Governance of distribution channels and standards would ensure that products achieved an acceptable level of certification.

Finally, transitioning to a bioeconomy that integrates forest foods should be approached from a global justice perspective because a significant share of forest food species (current and potential) originate from tropical and subtropical ecosystems. Many consuming countries are economically advanced, yet source products from the Global South. The global nature of food systems obligates consuming countries wanting to transition to a bioeconomy to consider and mitigate the impacts of consumption of products from developing countries. Considering global inequality, this view proposes the pursuit of global egalitarian values rooted in humanitarianism and cosmopolitanism [145]. High-valued markets for healthy, sustainably produced lifestyle food products represent opportunities for entrepreneurial producers, although there is risk that a fad for such superfoods could end as another example of exploiting resources for short-lived consumer demands. Potential safeguards include access and benefit sharing agreements as stipulated by the Nagoya Protocol that aim to protect 
the customary knowledge and intellectual property rights of local communities in their resources [146]. Likewise, increasing the share of value-adding activities in the countries of origin notwithstanding the variety of logistical and technological challenges in current food supply chains can ensure that local producers and communities obtain a fair share of the benefits. Equally important will be to foster the use of locally produced forest food by local populations, which can contribute to the localization of food production.

\section{Conclusions}

Forests and trees are important sources of products for people's food security, nutrition, sovereignty, income/livelihoods, and culinary cultural identity. They provide fruit, nuts, vegetables, medicinal and aromatic plants, insects, and wild meat, rich in micro and macronutrients that many people lack. They are important to the basic sustenance of rural and urban, poor and affluent people, worldwide, who directly and indirectly consume non-timber forest products. Forests and trees provide "security nets" for food products during droughts and other environmentally stressful times. They enrich the culinary culture of people throughout. The diversity of spatial and temporal factors that affect forests and trees in providing food products needs full consideration to reintegrate and expand these resources into food systems.

Foraging forest foods is expanding globally, and this trend is expected to continue as populations increase and consumer demand evolves. This use of forests increases pressures on biodiversity, putting excess strain on plant populations that are impacted by gathering products. While the harvest of some plant organs (e.g., fruits and nuts) may not impact populations, the harvest of other organs (e.g., roots, tubers) can have significant impact on sustainability.

At the same time, foraging is supporting a renaissance among urbanites who are a driving force in global markets for sustainably sourced forest foods, which requires scrutiny and verification through appropriate certification. With continued education of an expanding demographic worldwide demand for sustainably produced forest foods can be expected to grow. Unfortunately, there are public health concerns, such as transmission of viruses and disease from animals to humans, associated with consumption of forests foods.

Forest foods are produced in myriad of systems, from wild-harvesting natural populations to intense single-species plantings. Over generations, people living near forests, and dependent on them for sustenance, have developed formal and informal management practices that could support more prescription management strategies of open-access or communal forest lands to support sustainable sourcing of much needed foods. There are opportunities across rural and urban landscapes to integrate trees into food systems and support transition to a bioeconomy. Agroforestry systems with native fruit trees and traditional forest foods can contribute important macro- and micronutrients needed to achieve nutrition and food security objectives. Orchards and plantations are important sources of large volumes of nutritious foods, although loss of biodiversity by converting natural forests to single plantings must be fully considered and avoided. The spectrum of production systems will be required to achieve food security and nutrition.

Realigning forest production systems to a bioeconomy model is a process that may take decades. In some perspectives, that process has been underway for many years, as is evident by efforts to ensure Fair Trade, certification of production, and sustainability of sourcing. It will require involvement of all stakeholders, from individual farmers to international level policy makers. Providing forest foods to local and external markets will require integration of forests and trees across a mosaic of production landscapes. Innovations and technology development are essential for a transition to a bioeconomy with forest foods. Ultimately, transition to a bioeconomy where forests and trees are integral to food systems will be driven by consumer demand, which can be influenced through social marketing and education that is supported by research on such matters as phytochemistry, traditional practices, and sustainable production methods. 
Author Contributions: All authors contributed to the preparation of this manuscript. J.L.C. conceived the concept for the article and invited the other authors to contribute because of their international expertise. J.L.C., D.D., and K.M., contributed to the initial draft of the manuscript, and all subsequent drafts. All authors have read and agreed to the published version of the manuscript.

Funding: This research received no external funding.

Acknowledgments: At the 2019 World Forest Congress in Curitiba, Brazil, the Board of the International Union of Forestry Research Organizations (IUFRO) commissioned the global task force "Unlocking the Bioeconomy and Nontimber Forest Products". The authors on this manuscript are members of the Task Force and represent two of the more than 25 institutions from over 23 countries involved in this effort. The expressed views of the authors do not necessarily represent that of their respective institutions. The task force is investigating how non-timber forest products can be integrated into global and national efforts to transition to a bioeconomy. The authors acknowledge the contribution of Giulia Muir, a Task Force member with UN FAO, to the earliest version of this manuscript, who due to COVID-19 was unable to continue adding to further development of this paper.

Conflicts of Interest: No conflicts of interest have been identified.

\section{References}

1. Green, R.E.; Cornell, S.J.; Scharlemann, J.P.W.; Balmford, A. Farming and the Fate of Wild Nature. Science 2005, 307, 550-555. [CrossRef] [PubMed]

2. FAO. Biodiversity for Food and Agriculture: Contributing to Food Security and Sustainability in a Changing World; PAR Platform, FAO: Rome, Italy, 2011.

3. Jaggard, K.W.; Qi, A.; Ober, E.S. Possible changes to arable crop yields by 2050. Philos. Trans. R. Soc. B Biol. Sci. 2010, 365, 2835-2851. [CrossRef] [PubMed]

4. Iizumi, T.; Furuya, J.; Shen, Z.; Kim, W.; Okada, M.; Fujimori, S.; Hasegawa, S.; Nishimori, M. Responses of crop yield growth to global temperature and socioeconomic changes. Sci. Rep. 2017, 7, 7800. [CrossRef] [PubMed]

5. Bahar, N.H.; Lo, M.; Sanjaya, M.; Van Vianen, J.; Alexander, P.; Ickowitz, A.; Sunderland, T. Meeting the food security challenge for nine billion people in 2050: What impact on forests? Glob. Environ. Chang. 2020, 62, 102056. [CrossRef]

6. FAO. The State of the World's Forests 2018: Forest Pathways to Sustainable Development; FAO: Rome, Italy, 2018.

7. Angelsen, A.; Jagger, P.; Babigumira, R.; Belcher, B.; Hogarth, N.J.; Bauch, S.; Börnder, J.; Smith-Hall, C.; Wunder, S. Environmental Income and Rural Livelihoods: A Global-Comparative Analysis. World Dev. 2014, 64, S12-S28. [CrossRef]

8. Pimentel, D.; McNair, M.; Duck, L.; Pimentel, M.; Kamil, J. The value of forests to world food security. Hum. Ecol. 1997, 25, 91-120. [CrossRef]

9. Penafiel, D.; Lachat, C.; Espinel, R.; van Damme, P.; Kolsteren, P. A systematic review on the contributions of edible plant and animal biodiversity to human diets. EcoHealth 2011, 8, 381-399. [CrossRef] [PubMed]

10. Ickowitz, A.; Powell, B.; Salim, M.A.; Sunderland, T.C. Dietary quality and tree cover in Africa. Glob. Environ. Chang. 2014, 24, 287-294. [CrossRef]

11. Nykänen, E.A.; Dunning, H.E.; Aryeetey, R.N.O.; Robertson, A.; Parlesak, A. Nutritionally optimized, culturally acceptable, cost-minimized diets for low income Ghanaian families using linear programming. Nutrients 2018, 10, 461. [CrossRef] [PubMed]

12. Mollee, E.; Pouliot, M.; McDonald, M.A. Into the urban wild: Collection of wild urban plants for food and medicine in Kampala, Uganda. Land Use Policy 2017, 63, 67-77. [CrossRef]

13. Aworh, O.C. From lesser-known to super vegetables: The growing profile of African traditional leafy vegetables in promoting food security and wellness. J. Sci. Food Agric. 2018, 98, 3609-3613. [CrossRef] [PubMed]

14. Nero, B.F.; Kwapong, N.A.; Jatta, R.; Fatunbi, O. Tree Species Diversity and Socioeconomic Perspectives of the Urban (Food) Forest of Accra, Ghana. Sustainability 2018, 10, 3417. [CrossRef]

15. Sneyd, L.Q. Wild food, prices, diets and development: Sustainability and food security in urban Cameroon. Sustainability 2013, 5, 4728-4759. [CrossRef]

16. Schlesinger, J.; Drescher, A.; Shackleton, C.M. Socio-spatial dynamics in the use of wild natural resources: Evidence from six rapidly growing medium-sized cities in Africa. Appl. Geogr. 2015, 56, 107-115. [CrossRef] 
17. Cloete, P.C.; Idsardi, E.F. Consumption of indigenous and traditional food crops: Perceptions and realities from South Africa. Agroecol. Sustain. Food Syst. 2013, 37, 902-914. [CrossRef]

18. HLPE. Sustainable Forestry for Food Security and Nutrition: A Report by the High Level Panel of Experts on Food Security and Nutrition of the Committee on World Food Security; FAO: Rome, Italy, 2017.

19. Ickowitz, A.; Rowland, D.; Powell, B.; Salim, M.A.; Sunderland, T. Forests, trees, and micronutrient-rich food consumption in Indonesia. PLoS ONE 2016, 11, e0154139. [CrossRef]

20. Chamberlain, J.; Teets, A.; Kruger, S. Nontimber Forest Products in the United States: An Analysis for the 2015 National Sustainability Report; General Technical Report SRS-229; U.S. Department of Agriculture, Forest Service, Southern Research Station: Asheville, NC, USA, 2018; 36p.

21. Lovrić, M.; Da Re, R.; Vidale, E.; Prokofieva, I.; Wong, J.; Pettenella, D.; Verkerk, P.J.; Mavsar, R. Non-wood forest products in Europe-A quantitative overview. For. Policy Econ. 2020, 116, 102175. [CrossRef]

22. Mwampamba, T.H.; Ghilardi, A.; Sander, K.; Chaix, K.J. Dispelling common misconceptions to improve attitudes and policy outlook on charcoal in developing countries. Energy Sustain. Dev. 2013, 17, 75-85. [CrossRef]

23. Brobbey, L.K.; Hansen, C.P.; Kyereh, B.; Pouliot, M. The economic importance of charcoal to rural livelihoods: Evidence from a key charcoal-producing area in Ghana. For. Policy Econ. 2019, 101, 19-31. [CrossRef]

24. Scheid, A.; Hafner, J.; Hoffmann, H.; Kächele, H.; Sieber, S.; Rybak, C. Fuelwood scarcity and its adaptation measures: An assessment of coping strategies applied by small-scale farmers in Dodoma region, Tanzania. Environ. Res. Lett. 2018, 13, 095004. [CrossRef]

25. Amare, D.; Mekuria, W.; Wondie, M.; Teketay, D.; Eshete, A.; Darr, D. Wood Extraction among the Households of Zege Peninsula, Northern Ethiopia. Ecol. Econ. 2017, 142, 177-184. [CrossRef]

26. Rehnus, M.; Nazarek, A.; Mamadzhanov, D.; Venglovsky, B.I.; Sorg, J.P. High demand for fuelwood leads to overuse of walnut-fruit forests in Kyrgyzstan. J. For. Res. 2013, 24, 797-800. [CrossRef]

27. Sola, P.; Schure, J.; Atyi, R.E.; Gumoo, D.; Okeyo, I.; AwoNo, A. Woodfuel policies and practices in selected countries in Sub-Saharan Africa-A critical review. Bois For. Trop. 2019, 340, 27-41. [CrossRef]

28. FAO-Food and Agriculture Organization of the United Nations. State of the World's Forests: Enhancing the Socioeconomic Benefits from Forests; FAO: Rome, Italy, 2014; 133p, ISBN 978-92-5-108269-0.

29. Powell, B.; Thilsted, S.H.; Ickowitz, A.; Termote, C.; Sunderland, T.; Herforth, A. Improving diets with wild and cultivated biodiversity from across the landscape. Food Secur. 2015, 7, 535-554. [CrossRef]

30. Sorrenti, S. Non-Wood Forest Products in International Statistical Systems; Non-Wood Forest Product Series No. 22; UN FAO: Rome, Italy, 2017.

31. Chamberlain, J.L.; Small, C.J.; Baumflek, M. Sustainable production of temperate and boreal nontimber forest products: Examples from North America. In Achieving Sustainable Management of Boreal and Temperate Forests; Stanturf, J.A., Ed.; Burleigh Dodds Science Publishing: Cambridge, UK, 2019. [CrossRef]

32. Anderson, M.K.; Lake, F.K. California Indian Ethnomycology and Associated Forest Management. J. Ethnobiol. 2013, 33, 33-85. [CrossRef]

33. Yasuoka, H. Long-term foraging expeditions (Molongo) among the baka hunter-gatherers in the northwestern Congo Basin, with special reference to the "wild yam question". Hum. Ecol. 2006, 34, 275-296. [CrossRef]

34. Katz, E.; Lopez, C.L.; Fleury, M.; Miller, R.P.; Paye, V.; Dias, T.; Silva, F.; Oliveira, Z.; Moreira, E. No greens in the forest? Note on the limited consumption of greens in the Amazon. Acta Soc. Bot. Pol. 2012, 81, 283-293. [CrossRef]

35. Landor-Yamagata, J.L.; Kowarik, I.; Fischer, L.K. Urban foraging in Berlin: People, plants and practices within the metropolitan green infrastructure. Sustainability 2018, 10, 1873. [CrossRef]

36. Baumflek, M.; Chamberlain, J.L. Ramps Reporting: What 70 years of popular media tells us about a cultural keystone species. Southeast. Geogr. 2019, 59, 77-96. [CrossRef]

37. Svanberg, I.; Lindh, H. Mushroom hunting and consumption in twenty-first century post-industrial Sweden. J. Ethnobiol. Ethnomed. 2019, 15, 42. [CrossRef] [PubMed]

38. Wiersum, K.F. New interest in forest products in Europe as an expression of biocultural dynamics. Hum. Ecol. 2017, 45, 787-794. [CrossRef] [PubMed]

39. Fischer, L.K.; Brinkmeyer, D.; Karle, S.J.; Cremer, K.; Huttner, E.; Seebauer, M.; Nowikow, U.; Schütze, B.; Voigt, P.; Völker, S.; et al. Biodiverse edible schools: Linking healthy food, school gardens and local urban biodiversity. Urban For. Urban Green. 2019, 40, 35-43. [CrossRef] 
40. Barreau, A.; Ibarra, J.T.; Wyndham, F.S.; Kozak, R.A. Shifts in Mapuche Food Systems in Southern Andean Forest Landscapes: Historical Processes and Current Trends of Biocultural Homogenization. Mt. Res. Dev. 2019, 39, R12-R23. [CrossRef]

41. Ali, J.; Kapoor, S.; Moorthy, J. Buying behavior of consumers for food products in an emerging economy. Br. Food J. 2010, 112, 109-124. [CrossRef]

42. Moser, R.; Raffaelli, R.; Thilmany-McFadden, D. Consumer Preferences for Fruit and Vegetables with Credence-Based Attributes: A Review. Int. Food Agribus. Manag. Rev. 2011, 14, 121-142. [CrossRef]

43. Rodrigues, D.M.; Rodrigues, J.F.; Rios de Souza, V.; Souza Carneiro, J.D.; Vilela Borges, S. Consumer preferences for Cerrado fruit preserves: A study using conjoint analysis. Br. Food J. 2018, 120, 827-838. [CrossRef]

44. Grunert, K.G. (Ed.) Consumer Trends and New Product Opportunities in the Food Sector; Wageningen Academic Publishers: Wageningen, The Netherlands, 2017.

45. Sardeshpande, M.; Shackleton, C. Wild edible fruits: A systematic review of an under-researched multifunctional NTFP (non-timber forest product). Forests 2019, 10, 467. [CrossRef]

46. Kuznesof, S.; Tregear, A.; Moxey, A. Region foods: A consumer perspective. Br. Food J. 1997, 99, $199-206$. [CrossRef]

47. Garekae, H.; Shackleton, C.M. Foraging wild food in urban spaces: The contribution of wild foods to urban dietary diversity in South Africa. Sustainability 2020, 12, 678. [CrossRef]

48. Lovrić, M.; Lovrić, N.; Mavsar, R. Mapping forest-based bioeconomy research in Europe. For. Policy Econ. 2019, 110, 101874. [CrossRef]

49. Mungofa, N.; Malongane, F.; Tabit, F.T. An exploration of the consumption cultivation and trading of indigenous leafy vegetables in rural communities in the greater Tubatse local municipality, Limpopo province, South Africa. J. Consum. Sci. 2018, 3, 53-67.

50. Maroyi, A. Potential role of traditional vegetables in household food security: A case study from Zimbabwe. Afr. J. Agric. Res. 2011, 6, 5720-5728.

51. Darr, D.; Chopi-Msadala, C.; Namakhwa, C.D.; Meinhold, K.; Munthali, C. Processed baobab (Adansonia igitate L.) food products in Malawi: From poor men's to premium-price specialty food? Forests 2020, 11, 698. [CrossRef]

52. Gebauer, J.; Assem, A.; Busch, E.; Hardtmann, S.; Möckel, D.; Krebs, F.; Ziegler, T.; Wichern, F.; Wiehle, M.; Kehlenbeck, K.D. Baobab (Adansonia digitata L.): Wildobst aus Afrika für Deutschland und Europa?! Erwerbs Obstbau 2014, 56, 9-24. [CrossRef]

53. Holmborn, B. Xylitol: A healthy sweetener from birch wood. Actual. Chim. 2002, 11-12, 52-53.

54. Lim, T.K. Edible Medicinal and Non-Medicinal Plants. Volume 1-6, Fruits; Springer: Dordrecht, The Netherlands, 2012. [CrossRef]

55. Wells, J.C.; Sawaya, A.L.; Wibaek, R.; Mwangome, M.; Poullas, M.S.; Yajnik, C.S.; Demaio, A. The double burden of malnutrition: Aetiological pathways and consequences for health. Lancet 2020, 395, 75-88. [CrossRef]

56. Popkin, B.M. Nutrition transition and the global diabetes epidemic. Curr. Diabetes Rep. 2015, 15, 64. [CrossRef]

57. Lachance, J.C.; Radhakrishnan, S.; Madiwale, G.; Guerrier, S.; Vanamala, J.K.P. Targeting hallmarks of cancer with a food-system-based approach. Nutrition 2020, 69, 110563. [CrossRef]

58. Sammugam, L.; Pasupuleti, V.R. Balanced diets in food systems: Emerging trends and challenges for human health. Crit. Rev. Food Sci. Nutr. 2019, 59, 2746-2759. [CrossRef]

59. Martens, F. Akute und chronische Vergiftungen mit Digitalisglykosiden. Notf. Hausarztmedizin 2005, 31, A306-A309. [CrossRef]

60. Ellwanger, J.H.; Kulmann-Leal, B.; Kaminski, V.L.; Valverde-Villegas, J.M.; Da Veiga, A.B.G.; Spilki, F.R.; Fearnside, P.M.; Caesar, L.; Giatti, L.L.; Wallau, G.L.; et al. Beyond diversity loss and climate change: Impacts of Amazon deforestation on infectious diseases and public health. An. Acad. Bras. Cienc. 2020, 92, e20191375. [CrossRef] [PubMed]

61. Akem, E.S.; Pemunta, N.V. The bat meat chain and perceptions of the risk of contracting Ebola in the Mount Cameroon region. BMC Public Health 2020, 20, 593. [CrossRef] [PubMed] 
62. Friant, S.; Ayambem, W.A.; Alobi, A.O.; Ifebueme, N.M.; Otukpa, O.M.; Ogar, D.A.; Alawa, C.B.I.; Goldberg, T.L.; Jacka, J.K.; Rothman, J.M. Eating Bushmeat Improves Food Security in a Biodiversity and Infectious Disease "Hotspot". EcoHealth 2020, 17, 125-138. [CrossRef] [PubMed]

63. Parrotta, J.A.; Dey de Pryck, J.; Obiri, B.D.; Padoch, C.; Powell, B.; Sandbrook, C.; Sandbrook, C. Chapter 3: Historical, Environmental and Socio-Economic Context of Forests and Tree-Based Systems for Food Security and Nutrition. In Forests, Trees and Landscapes for Food Security and Nutrition: A Global Assessment Report; IUFRO World Series Volume 33; Bhaskar, V., Wildburger, C., Mansourian, S., Eds.; IUFRO: Vienna, Austria, $2015 ; 172 p$.

64. Hladik, C.M.; Linares, O.F.; Hladik, A.; Pagezy, H.; Semple, A. Tropical forests, people and food: An overview. In Tropical Forests, People and Food. Biocultural Interactions and Applications to Development; Man and Biosphere Ser. 13; Hladik, C.M., Hladik, A., Linares, O.F., Pagezy, H., Semple, A., Hadley, M., Eds.; UNESCO: Paris, France; Parthenon: New York, NY, USA, 1993.

65. Boerboom, J.H.A.; Wiersum, K.F. Human impact on tropical moist forest. In Man's Impact on Vegetation; Holzner, W., Werger, M.J.A., Ikusima, I., Eds.; W Junk: The Hague, The Netherlands, 1983; pp. 83-106.

66. Sauer, C.O. Agricultural Origins and Dispersals, 2nd ed.; MIT Press: Cambridge, MA, USA; London, UK, 1969.

67. Garibaldi, A.; Turner, N. Cultural keystone species: Implications for ecological conservation and restoration. Ecol. Soc. 2004, 9. [CrossRef]

68. Silva, R.R.; Gomes, L.J.; Albuquerque, U.P. Plant extractivism in light of game theory: A case study in northeastern Brazil. J. Ethnobiol. Ethnomed. 2015, 11, 6. [CrossRef]

69. Anderson, K. Tending the Wild: Native American Knowledge and the Management of California's Natural Resources; University of California Press: Berkeley, CA, USA, 2005; 588p, ISBN 9780520280434.

70. Chamberlain, J.L.; Emery, M.R.; Patel-Weynand, T. (Eds.) Assessment of Nontimber Forest Products in the United States under Changing Conditions; General Technical Report SRS-232; U.S. Department of Agriculture, Forest Service, Southern Research Station: Asheville, NC, USA, 2018; 260p.

71. Schmidt, J.P.; Cruse-Sanders, J.; Chamberlain, J.L.; Ferreira, S.; Young, J.A. Explaining harvests of wild-harvested herbaceous plants: American ginseng as a case study. Biol. Conserv. 2019, 231, 139-149. [CrossRef]

72. Tieguhong, J.C.; Ingram, V.; Mala, W.A.; Ndoye, O.; Grouwels, S. How governance impacts non-timber forest product value chains in Cameroon. For. Policy Econ. 2015, 61, 1-10. [CrossRef]

73. Wynberg, R.P.; Laird, S.A. Less is often more: Governance of a non-timber forest product, marula (Sclerocarya birrea subsp. caffra) in southern Africa. Int. For. Rev. 2007, 9, 475-490. [CrossRef]

74. Chamberlain, J.; Small, C.; Baumflek, M. Sustainable Forest Management of Nontimber Forest Products. Sustainability 2019, 11, 2670. [CrossRef]

75. Pilz, D.; Molina, R.; Mayo, J. Effects of thinning young forests on chanterelle mushroom production. J. For. 2006, 104, 9-14.

76. Schmidt, M. Mensch und Umwelt in Kirgistan: Politische Ökologie im postkolonialen und postsozialistischen Kontext; Erdkundliches Wissen Band 153; Franz Steiner: Stuttgart, Germany, 2013.

77. Sorg, J.P.; Urech, Z.L.; Mamadzhanov, D.; Rehnus, M. Thinning effects on walnut stem and crown diameter growth and fruiting in the walnut-fruit forests of Kyrgyzstan. J. Mt. Sci. 2016, 13, 1558-1566. [CrossRef]

78. Ellum, D. Demographic Patterns and Disturbance Responses of Understory Vegetation in a Managed Forest of Southern New England: Implications for Sustainable Forestry and Biodiversity. Ph.D. Dissertation, Yale University, New Haven, CT, USA, 2007; 235p.

79. Duguid, M.C.; Frey, B.R.; Ellum, D.S.; Kelty, M.; Ashton, M.S. The influence of ground disturbance and gap position on understory plant diversity in upland forests of southern New England. For. Ecol. Manag. 2013, 303, 148-159. [CrossRef]

80. Pierce, A. Sugar Maple (Acer saccharum). In Tapping the Green Market: Certification and Management of Non-Timber Forest Products; Laird, S.A., Guillen, A., Pierce, A.R., Eds.; Earthscan Publications: Sterling, VA, USA, 2002; pp. 162-171.

81. Zomer, R.J.; Trabucco, A.; Coe, R.; Place, F.; van Noordwijk, M.; Xu, J.C. Trees on Farms: An Update and Reanalysis of Agroforestry's Global Extent and Socio-Ecological Characteristics; Working Paper 179; World Agroforestry Centre (ICRAF) Southeast Asia Regional Program: Bogor, Indonesia, 2014. [CrossRef]

82. Amare, D.; Wondie, M.; Mekuria, W.; Darr, D. Agroforestry of smallholder farmers in Ethiopia: Practices and benefits. Small Scale For. 2019, 18, 39-56. [CrossRef] 
83. Whitney, C.W.; Luedeling, E.; Tabuti, J.R.S.; Nyamukuru, A.; Hensel, O.; Gebauer, J.; Kehlenbeck, K. Crop diversity in homegardens of southwest Uganda and its importance for rural livelihoods. Agric. Hum. Values 2018, 35, 399-424. [CrossRef]

84. Assogbadjo, A.E.; Glèlè, K.R.; Vodouhê, F.G.; Djagoun, C.A.M.S.; Codjia, J.T.C.; Sinsin, B. Biodiversity and socioeconomic factors supporting farmers' choice of wild edible trees in the agroforestry systems of Benin (West Africa). For. Policy Econ. 2012, 14, 41-49. [CrossRef]

85. Leakey, R.; van Damme, P. The role of tree domestication in green market product value chain development. For. Trees Livelihoods 2014, 23, 116-126. [CrossRef]

86. Reed, J.; van Vianen, J.; Foli, S.; Clendenning, J.; Yang, K.; MacDonald, M.; Petrokofsky, G.; Padoch, C.; Sunderland, T. Trees for life: The ecosystem service contribution of trees to food production and livelihoods in the tropics. For. Policy Econ. 2017, 84, 62-71. [CrossRef]

87. Fifanou, V.G.; Ousmane, C.; Gauthier, B.; Brice, S. Traditional agroforestry systems and biodiversity conservation in Benin (West Africa). Agrofor. Syst. 2011, 82, 1-13. [CrossRef]

88. Apuri, I.; Peprah, K.; Achana, G.T.W. Climate change adaptation through agroforestry: The case of Kassena Nankana West District, Ghana. Environ. Dev. 2018, 28, 32-41. [CrossRef]

89. Félix, G.F.; Diedhiou, I.; Le Garff, M.; Timmermann, C.; Clermont-Dauphin, C.; Cournac, L.; Groot, J.C.J.; Tittonell, P. Use and management of biodiversity by smallholder farmers in semi-arid West Africa. Glob. Food Secur. 2018, 18, 76-85. [CrossRef]

90. Whitney, C.W.; Tabuti, J.R.S.; Hensel, O.; Yeh, C.H.; Gebauer, J.; Luedeling, E. Homegardens and the future of food and nutrition security in southwest Uganda. Agric. Syst. 2017, 154, 133-144. [CrossRef]

91. Jamnadass, R.H.; Dawson, I.K.; Franzel, S.; Leakey, R.R.B.; Mithöfer, D.; Akinnifesi, F.K.; Tchoundjeu, Z. Improving livelihoods and nutrition in sub-Saharan Africa through the promotion of indigenous and exotic fruit production in smallholders' agroforestry systems: A review. Int. For. Rev. 2011, 13, 338-354. [CrossRef]

92. Gruère, G.; Giuliani, A.; Smale, M. Marketing Underutilized Plant Species for the Benefit of the Poor: A Conceptual Framework; EPT Discussion Paper \#154; Intl Food Policy Res Inst.: Washington, DC, USA, 2006.

93. Leakey, R.R.B.; Tchoundjeu, Z.; Schreckenberg, K.; Shackleton, S.E.; Shackleton, C.M. Agroforestry Tree Products (AFTPs): Targeting Poverty Reduction and Enhanced Livelihoods. Int. J. Agric. Sustain. 2005, 3, 1-23. [CrossRef]

94. Meinhold, K.; Darr, D. The Processing of Non-Timber Forest Products through Small and Medium Enterprises-A Review of Enabling and Constraining Factors. Forests 2019, 10, 1026. [CrossRef]

95. Meinhold, K.; Darr, D. Using a multi-stakeholder approach to increase value for traditional agroforestry systems: The case of baobab (Adansonia digitata L.) in Kilifi, Kenya. Agrofor. Syst. 2020, resubmitted.

96. Smith, N.J.H.; Williams, J.T.; Plucknett, D.L.; Talbot, J.P. Tropical Forests and Their Crops; Cornell University Press: Ithaca, NY, USA, 1992.

97. Watson, G.A. Tree crops and farming systems development in the humid tropics. Exp. Agric. 1990, 26, 143-159. [CrossRef]

98. Muir, G.F.; Sorrenti, S.; Vantomme, P.; Vidale, E.; Masiero, M. Into the wild: Disentangling non-wood terms and definitions for improved forest statistics. Int. For. Rev. 2020, 22, 101-119. [CrossRef]

99. Venter, S.M.; Witkowski, E.T.F. Baobab (Adansonia digitata L.) density, size-class distribution and population trends between four land-use types in northern Venda, South Africa. For. Ecol. Manag. 2010, 259, $294-300$. [CrossRef]

100. Yan, M.; Terheggen, A.; Mithöfer, D. Who and what set the price of walnut for small scale farmers in Southwest China? J. Agribus. Dev. Merging Econ. 2017, 7, 135-152. [CrossRef]

101. FAOSTAT. Production Quantity and Area Harvested of Walnuts, with Shell (1961-2018). 2020. Available online: http://faostat.fao.org/site/567/DesktopDefault.aspx?PageID=567 (accessed on 24 June 2020).

102. Shigaeva, J.; Darr, D. On the socio-economic importance of natural and planted walnut (Juglans regia L.) forests in the Silk Road countries: A systematic review. For. Policy Econ. 2020, accepted. [CrossRef]

103. Malhotra, S.P. World Edible Nuts Economy; Concept Publishing: New Delhi, India, 2008.

104. Vahdati, K.; Hassani, D.; Rezaee, R.; Jafari, M.H.; Sayadi, S.; Khorami, S. Following Walnut Footprint in Iran. In Following Walnut Footprints (Juglans regia L.): Cultivation and Culture, Folklore and History, Traditions and Uses; Avanzato, D., McGranahan, G.H., Vahdati, K., Botu, M., Iannamico, L., Assche, J.V., Eds.; Scripta Horticulturae (Scripta Horticulturae 17): Leuven, Belgium, 2014. 
105. Angel, S.; Parent, J.; Civco, D.; Blei, A.; Potere, D. A Planet of Cities: Urban Land Cover Estimates and Projections for All Countries, 2000-2050; Lincoln Institute of Land Policy Working Paper; Lincoln Institute of Land Policy: Cambridge, MA, USA, 2010; 103p.

106. Clark, K.H.; Nicholas, K.A. Introducing urban food forestry: A multifunctional approach to increase food security and provide ecosystem services. Landsc. Ecol. 2013, 28, 1649-1669. [CrossRef]

107. Shackleton, C.; Hurley, P.T.; Dahlberg, A.C.; Emery, M.R.; Nagendra, H. Urban foraging: A Ubiquitous Human Practice Overlooked by Urban Planners, Policy, and Research. Sustainability 2017, 9, 1884. [CrossRef]

108. McLain, R.; Poe, M.; Hurley, P.; Lecompte-Mastenbrook, J.; Emery, M. Producing edible landscapes in Seattle's urban forest. Urban For. Urban Green. 2012, 11, 187-194. [CrossRef]

109. Poe, M.R.; McLain, R.J.; Emery, M.; Hurley, P.T. Urban forest justice and the rights to wild foods, medicines, and materials in the city. Hum. Ecol. 2013, 41, 409-422. [CrossRef]

110. Gori, A.; Ferrini, F.; Fini, A. Growing healthy food under heavy metal pollution load: Overview and major challenges of tree based edible landscapes. Urban For. Urban Green. 2019, 38, 403-406. [CrossRef]

111. Schlecht, M.T.; Säumel, I. Wild growing mushrooms for the Edible City? Cadmium and lead content in edible mushrooms harvested within the urban agglomeration of Berlin, Germany. Environ. Pollut. 2015, 204, 298-305. [CrossRef] [PubMed]

112. Stark, P.B.; Miller, D.; Carlson, T.J.; de Vasquez, K.R. Open-source food: Nutrition, toxicology, and availability of wild edible greens in the East Bay. PLoS ONE 2019, 14, e0202450. [CrossRef]

113. Shmatkov, N.; Brigham, T. Non-timber forest products in community development: Lessons from the Russian Far East. For. Chron. 2003, 79, 113-118. [CrossRef]

114. Ingram, V.; Ewane, M.; Ndumbe, L.N.; Awono, A. Challenges to governing sustainable forest food: Irvingia spp. from southern Cameroon. For. Pol. Econ. 2017, 84, 29-37. [CrossRef]

115. Buchmann, C.; Prehsler, S.; Hartl, A.; Vogl, C.R. The importance of baobab (Adansonia digitata L.) in rural West African subsistence-Suggestion of a cautionary approach to international market export of baobab fruits. Ecol. Food Nutr. 2010, 49, 145-172. [CrossRef]

116. Hermann, M. The impact of the European Novel Food Regulation on trade and food innovation based on traditional plant foods from developing countries. Food Policy 2009, 34, 499-507. [CrossRef]

117. Heinrich, M.; Scotti, F.; Andrade-Cetto, A.; Berger-Gonzalez, M.; Echeverria, J.; Friso, F.; Garcia-Cardona, F.; Hesketh, A.; Hitziger, M.; Maake, C.; et al. Access and Benefit Sharing Under the Nagoya Protocol—Quo Vadis? Six Latin American Case Studies Assessing Opportunities and Risk. Front. Pharmacol. 2020, 11, 765. [CrossRef] [PubMed]

118. ISFT. Food System Framework: A Focus on Food Sustainability; Institute of Food Science + Technology: London, UK, 2018. Available online: http://www.3keel.com/wp-content/uploads/reports/IFST\%20Sustainable\% 20Food\%20System\%20Framework_0.pdf (accessed on 17 September 2020).

119. Duchesne, L.; Wetzel, S. The bioeconomy and the forestry sector: Changing markets and new opportunities. For. Chron. 2003, 79, 860-864. [CrossRef]

120. Dietz, T.; Börner, J.; Förster, J.J.; Braun, J.V. Governance of the Bioeconomy: A Global Comparative Study of National Bioeconomy Strategies. Sustainability 2018, 10, 3190. [CrossRef]

121. Hetemäki, L.; Hanewinkel, M.; Muys, B.; Ollikainen, M.; Palahí, M.; Trasobares, A. Leading the Way to a European Circular Bioeconomy Strategy. From Science to Policy 5; European Forest Institute: Joensuu, Finland, 2017; 52p. [CrossRef]

122. Pülzl, H.; Kleinschmit, D.; Arts, B. Bioeconomy-An emerging meta-discourse affecting forest discourses? Scandinavian. J. For. Res. 2014, 29, 386-393. [CrossRef]

123. Albrecht, S.; Gottschick, M.; Schorling, M.; Stint, S. Bio-economy at a crossroads. Way forward to sustainable production and consumption or industrialization of biomass? Gaia Ecol. Perspect. Sci. Soc. 2012, 21, $33-37$.

124. Levidow, L.; Birch, K.; Papaioannou, T. Divergent paradigms of European agro-food innovation: The knowledge-based bio-economy (KBBE) as an R\&D agenda. Sci. Technol. Hum. Values 2013, 38, 94-125.

125. Behan, R.W. Multiresource forest management: A paradigmatic challenge to professional forestry. J. For. 1990, 88, 12-18.

126. Galindo-Leal, C.; Bunnell, F.L. Ecosystem management: Implications and opportunities of a new paradigm. For. Chron. 1995, 71, 601-606. [CrossRef]

127. Lackey, R.T. Seven pillars of ecosystem management. Landsc. Urban Plan. 1998, 40, 21-30. [CrossRef] 
128. Leakey, R.R.B. Potential for novel food products from agroforestry trees: A review. Food Chem. 1999, 66, 1-14. [CrossRef]

129. Devappa, R.K.; Rakshit, S.K.; Dekker, R.F.H. Forest biorefinery: Potential of poplar phytochemicals as value-added co-products. Biotechnol. Adv. 2015, 33, 681-716. [CrossRef] [PubMed]

130. Serrat, O. The future of social marketing. In Knowledge Solutions; Springer: Singapore, 2017; pp. 119-128.

131. McKenzie-Mohr, D. Fostering Sustainable Behavior: An Introduction to Community-Based Social Marketing; New Society Publishers: Gabriola Island, BC, Canada, 2011; 171p.

132. Albuquerque, B.R.; Oliveira, M.B.P.P.; Barros, L.; Ferreira, I.C.F.R. Could fruits be a reliable source of food colorants? Pros and cons of these natural additives. Crit. Rev. Food Sci. Nutr. 2020. [CrossRef] [PubMed]

133. Classen, H.G.; Elias, P.S.; Hammes, W.P.; Winter, M. Toxikologisch-Hygienische Beurteilung von Lebensmittelinhaltsstoffen und Zusatzstoffen; Behr's Verlag: Hamburg, Germany, 2001.

134. Celeja, C.; Barros, L.; Barreira, J.C.M.; Soković, M.; Calhelha, R.C.; Bento, A.; Oliveira, M.B.P.P.; Ferreira, I.C.F.R. Castanea sativa male flower extracts as an alternative additive in the Portuguese pastry delicacy "pastel de nata". Food Funct. 2020, 11, 2208-2217. [CrossRef] [PubMed]

135. Chang, S.K.; Alasalvar, C.; Shahidi, F. Superfruits: Phytochemicals, antioxidant efficacies, and health effects-A comprehensive review. Crit. Rev. Food Sci. Nutr. 2019, 59, 1580-1604. [CrossRef] [PubMed]

136. West, B.J.; Deng, S.; Isami, F.; Uwaya, A.; Jensen, C.J. The Potential Health Benefits of Noni Juice: A Review of Human Intervention Studies. Foods 2018, 7, 58. [CrossRef]

137. Coe, S.A.; Clegg, M.; Armengol, M.; Ryan, L. The polyphenol-rich baobab fruit (Adansonia digitata L.) reduces starch digestion and glycemic response in humans. Nutr. Res. 2013, 33, 888-896. [CrossRef] [PubMed]

138. Aworh, C.O. Promoting food security and enhancing Nigeria's small farmers' income through value-added processing of lesser-known and under-utilized indigenous fruits and vegetables. Food Res. Int. 2015, 76, 986-991. [CrossRef]

139. Mahapatra, A.K.; Shackleton, C.M. Exploring the relationships between trade in natural products, cash income and livelihoods in tropical forest regions of Eastern India. Int. For. Rev. 2012, 14, 62-73. [CrossRef]

140. Shackleton, S.; Shanley, P.; Ndoye, O. Invisible but viable: Recognising local markets for non-timber forest products. Int. For. Rev. 2007, 9, 697-712. [CrossRef]

141. Botelho, A.1.; Dinis, I.; Lourenco-Gomes, L.; Moneira, J.; Pinto, L.C.; Simoes, O. The effect of sequential information on consumers' willingness to pay for credence food attributes. Appetite 2017, 118, 17-25. [CrossRef] [PubMed]

142. Hoke, O.; Campbell, B.; Brand, M.; Thao, H. Impact of Information on Northeastern U.S. Consumer Willingness to Pay for Aronia Berries. HortSciences 2017, 52, 395-400. [CrossRef]

143. Codex Alimentarius International Food Standards. 2020. Available online: http://www.fao.org/fao-whocodexalimentarius/codex-texts/list-standards/en/ (accessed on 21 September 2020).

144. Smanalieva, J.; Iskakova, J.; Oskonbaeva, Z.; Wichern, F.; Darr, D. Determination of physicochemical parameters, phenolic content, and antioxidant capacity of wild cherry plum (Prunus divaricata Ledeb.) from the walnut-fruit forests of Kyrgyzstan. Eur. Food Res. Technol. 2019, 245, 2293-2301. [CrossRef]

145. Landesman, B.M. Global Justice. In Encyclopedia of Global Justice; Chatterjee, D.K., Ed.; Springer: Dordrecht, The Netherlands, 2011.

146. Teran, M.Y. The Nagoya Protocol and Indigenous Peoples. Int. Indig. Policy J. 2016, 7. [CrossRef]

Publisher's Note: MDPI stays neutral with regard to jurisdictional claims in published maps and institutional affiliations.

(C) 2020 by the authors. Licensee MDPI, Basel, Switzerland. This article is an open access article distributed under the terms and conditions of the Creative Commons Attribution (CC BY) license (http://creativecommons.org/licenses/by/4.0/). 